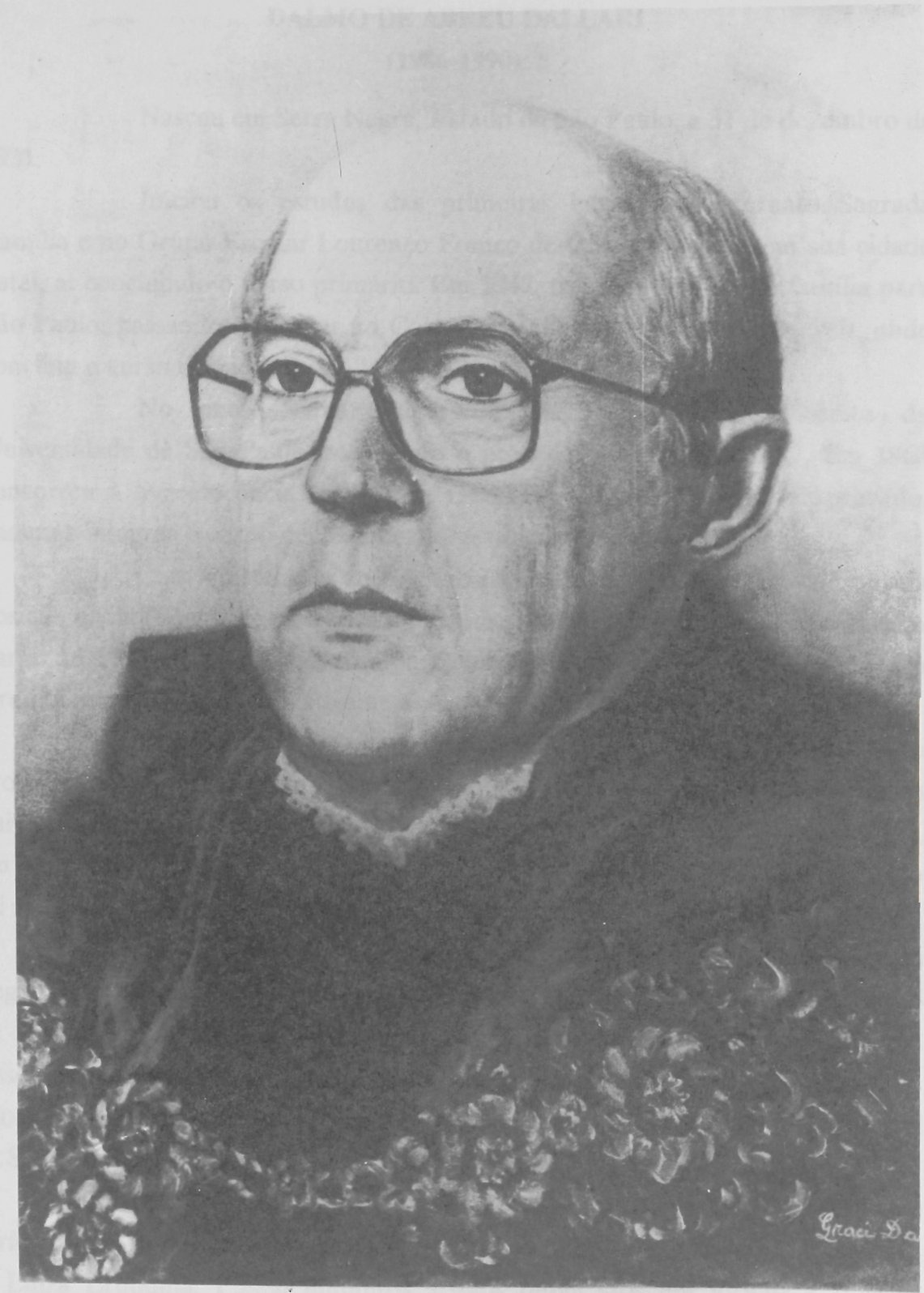

DALMO DE ABREU DALLARI 



\section{DALMO DE ABREU DALLARI}

(1986-1990)

Nasceu em Serra Negra, Estado de São Paulo, a 31 de dezembro de 1931.

Iniciou os estudos das primeiras letras no Externato Sagrada Familia e no Grupo Escolar Lourenço Franco de Oliveira, ambos em sua cidade natal, aí concluindo o curso primário. Em 1947, transferiu-se com a família para São Paulo, passando a estudar no Colégio Estadual Presidente Roosevelt, onde concluiu o curso clássico em 1952.

No ano seguinte ingressou na Faculdade de Direito da Universidade de São Paulo, recebendo o grau de bacharel em 1957. Em 1963 concorreu à livre-docência em Teoria Geral do Estado; tendo sido aprovado, passou a integrar o corpo docente desta Faculdade em 1964.

Com a instalação do governo revolucionário, passou a ter destacada posição na resistência democrática e na oposição ao regime que se estabelecia. A partir de 1972, ajudou a organizar a Comissão Pontifícia de Justiça e Paz da Arquidiocese de São Paulo, ativa na defesa dos Direitos Humanos.

No ano de 1974, venceu o concurso de títulos e provas para professor titular de Teoria Geral do Estado, vindo a prosseguir suas atividades universitárias, ministrando aulas no curso de pós-graduação desta Faculdade e, em 1986, foi escolhido para seu diretor, permanecendo até 1990. Na sua gestão foi iniciada a construção do prédio anexo da Faculdade.

Foi membro do Conselho Universitário e da Comissão de Legislação e Recursos da Universidade de São Paulo. É membro da Comissão de Justiça e Paz da Arquidiocese de São Paulo, da qual foi presidente, da Associação Brasileira de Juristas Democratas, do Instituto dos Advogados de São Paulo, do qual foi vice-presidente, além de ter presidido a Fundação Escola de Sociologia e Política.

De agosto de 1990 a dezembro de 1992 foi secretário dos Negócios Jurídicos da Prefeitura do Município de São Paulo, na gestão da prefeita D. Luiza Erundina. Possui inúmeros artigos publicados em jornais e revistas especializadas, além de ser colaborador do jornal Folha de S. Paulo. 


\section{Obras Publicadas}

O município brasileiro. São Paulo : s.c.p., 1961.

Da atualização do Estado. São Paulo : s.c.p., 1963.

Elementos de teoria geral do Estado. 14ª ed. São Paulo : Saraiva, 1989.

$O$ renascer do direito: direito e vida social; aplicação do direito, direito e política.

São Paulo : José Bushatsky, 1976.

O pequeno exército paulista. São Paulo : Perspectiva, 1977.

O futuro do Estado. São Paulo : Moderna, 1980.

Que são direitos da pessoa. São Paulo : Brasiliense, 1981.

Que é participação política. São Paulo : Brasiliense, 1981.

Constituição e Constituinte. São Paulo : Saraiva, 1982.

O direito da criança ao respeito. São Paulo : Summus, 1986.

O Estado Federal. São Paulo : Ática, 1986.

Direito ambiental. Revista Politécnica. São Paulo, n. 204-205, jan./jun. 1992. p. 23-24.

A participação popular e suas conquistas. In: Cidadão constituinte: a saga das emendas populares. Coord. Carlos Michiles et al. Rio de Janeiro : Paz e Terra, 1989. p. 378-388.

O Poder Judiciário e a filosofia jurídica na nova Constituição. In: Poder Judiciário e a nova Constituição. São Paulo : Lex, 1990. p. 9-23. 